\title{
DAMPAK MOTIVASI TERHADAP PENINGKATAN KINERJA INDIVIDU
}

\author{
Adie Erar Yusuf \\ Character Building Development Center, BINUS University \\ Jln. Kemanggisan Ilir III No. 45, Kemanggisan - Palmerah, Jakarta 11480 \\ ayusuf@binus.edu
}

\begin{abstract}
Individual's performance is influenced by various factors, as: motivation, competency, environment, and technology. High working motivation is expected to improve performance in the organization. It needs various planned and systematic techniques to improve the motivation to be effective. Based on motivation theories, motivation is the underlying reason for an individual to do something. Individuals who have high motivation might mean that they have reasonable cause to achieve the expected performance. In contrast, individuals with low motivation certainly cannot contribute optimally for towards their performance.
\end{abstract}

Keywords: motivation, motivation theories, achievement motivation

\begin{abstract}
ABSTRAK
Kinerja individu dipengaruhi oleh berbagai faktor, seperti: motivasi, kompetensi, lingkungan, dan teknologi. Motivasi kerja yang tinggi diharapkan akan meningkatkan kinerja dalam organisasi. Untuk meningkatkan motivasi diperlukan berbagai teknik yang terencana dan sistematis agar efektif. Berdasarkan teori motivasi, motivasi merupakan alasan yang mendasari individu melakukan sesuatu. Individu yang memiliki motivasi tinggi dapat berarti individu tersebut memiliki alasan kuat untuk mencapai kinerja yang diharapkan. Sebaliknya, individu dengan motivasi rendah dipastikan tidak dapat memberikan kontribusi optimal atas kinerjanya.
\end{abstract}

Kata kunci: motivasi, teori motivasi, motivasi berprestasi 


\section{PENDAHULUAN}

Masalah motivasi banyak dibicarakan di berbagai forum diskusi dan media elektronik yang disampaikan oleh para motivator. Hal ini menunjukkan bahwa motivasi merupakan salah satu faktor kunci dalam meningkatkan kehidupan khususnya pekerjaan dan karir seseorang. Sumber daya manusia merupakan aset utama organisasi dan memiliki peran penting sebagai perencana, pelaksana, dan pengendali kegiatan organisasi. Untuk mencapai tujuan organisasi, dituntut orang-orang yang memiliki motivasi tinggi dengan perhatian dan dedikasi kerja yang besar untuk menyelesaikan pekerjaan. Motivasi kerja yang tinggi diharapkan akan meningkatkan kinerja dalam organisasi. Untuk meningkatkan motivasi diperlukan berbagai teknik yang terencana dan sistematis agar efektif dan berdampak positif terhadap peningkatan kinerja.

Selama lebih dari puluhan tahun misteri motivasi dan kinerja diungkap oleh para pakar psikologi untuk mencari akar masalah terjadinya motivasi dan demotivasi dalam diri individu khususnya dalam suatu organisasi. Menurut pakar psikologi seperti Maslow dengan teori kebutuhan dan Herzberg dengan teori dua faktor, bahwa gaji/upah, sistem dan prosedur, fasilitas dan kondisi kerja merupakan kebutuhan dasar yang harus dipenuhi namun tidak signifikan meningkatkan motivasi (Ismail, 2012). Sedangkan untuk meningkatkan motivasi secara optimal dibutuhkan faktor-faktor motivasi yang lebih dari sekedar pemenuhan kebutuhan dasar. Beberapa ahli psikologi lain bahkan ada yang melakukan riset untuk mengkaji terjadinya motivasi dalam melakukan aktivitas dan menentukan faktor-faktor yang dapat meningkatkan motivasi atau menurunkan motivasi individu.

\section{METODE}

Penelitian ini menggunakan pendekatan studi literatur, yaitu mencari berbagai sumber yang terkait dengan konsep dan prinsip-prinsip motivasi serta teori-teori motivasi serta pengaruhnya terhadap kinerja individu. Studi literatur yang dipelajari dan dianalisis secara komprehensif dijadikan bahan pendukung untuk mendeskripsikan dampak motivasi terhadap peningkatan kinerja dalam suatu organisasi.

\section{HASIL DAN PEMBAHASAN}

Istilah motivasi berasal dari bahasa latin yaitu movere yang berarti bergerak atau menggerakkan. Motivasi diartikan juga sebagai suatu kekuatan sumber daya yang menggerakkan dan mengendalikan perilaku manusia. Motivasi sebagai upaya yang dapat memberikan dorongan kepada seseorang untuk mengambil suatu tindakan yang dikehendaki, sedangkan motif sebagai daya gerak seseorang untuk berbuat. Karena perilaku seseorang cenderung berorientasi pada tujuan dan didorong oleh keinginan untuk mencapai tujuan tertentu.

Dalam konteks pekerjaan, motivasi merupakan salah satu faktor penting dalam mendorong seorang individu untuk bekerja. Motivasi adalah kesediaan individu untuk mengeluarkan upaya yang tinggi untuk mencapai tujuan organisasi (Robbins, 2001). Ada tiga elemen kunci dalam motivasi yaitu upaya, tujuan organisasi dan kebutuhan. Upaya merupakan ukuran intensitas. Jika seseorang termotivasi, ia akan berupaya sekuat tenaga untuk mencapai tujuan namun belum tentu upaya yang tinggi akan menghasilkan kinerja yang tinggi. Oleh karena itu, diperlukan intensitas dan kualitas dari upaya tersebut serta difokuskan pada tujuan organisasi. Kebutuhan adalah kondisi internal yang menimbulkan dorongan, yang jika kebutuhan tersebut tidak terpuaskan akan menimbulkan tegangan 
yang merangsang dorongan dari dalam diri individu. Dorongan ini menimbulkan perilaku pencarian untuk menemukan tujuan tertentu. Jika ternyata terjadi pemenuhan kebutuhan, akan terjadi pengurangan tegangan. Pada dasarnya, individu yang termotivasi berada dalam kondisi tegang dan berupaya mengurangi ketegangan dengan mengeluarkan upaya.

Proses motivasi yang menunjukkan kebutuhan yang tidak terpuaskan akan meningkatkan tegangan dan memberikan dorongan pada seseorang dan menimbulkan perilaku digambarkan sebagai berikut.

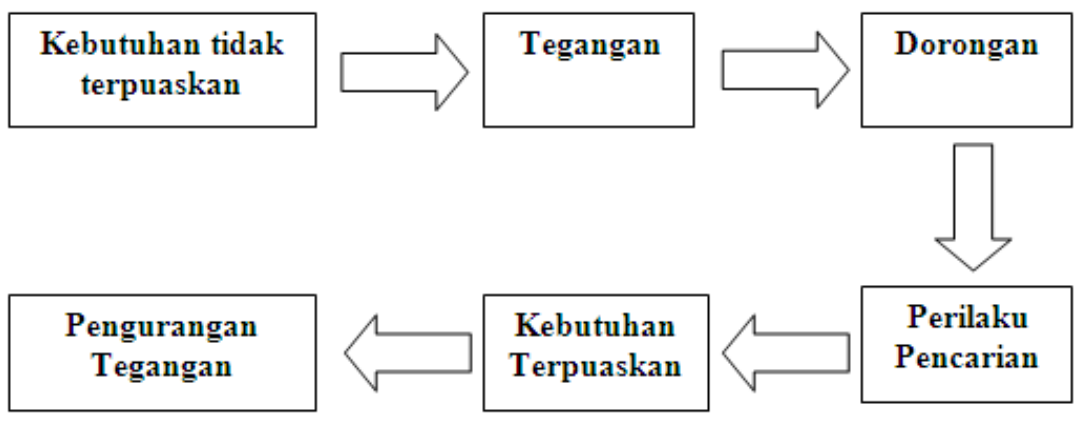

Gambar 1 Proses Motivasi

Pada umumnya kinerja yang tinggi dihubungkan dengan motivasi yang tinggi. Sebaliknya, motivasi yang rendah dihubungkan dengan kinerja yang rendah. Kinerja seseorang kadang-kadang tidak berhubungan dengan kompetensi yang dimiliki karena terdapat faktor diri dan lingkungan kerja yang memengaruhi kinerja. Kinerja yang tinggi adalah fungsi dan interaksi antara motivasi, kompetensi, dan peluang sumber daya pendukung. Dengan demikian, kinerja dapat dirumuskan sebagai berikut:

\section{Kinerja $=f($ Motivasi $x$ Kompetensi $x$ Kesempatan $)$}

Terdapat 5 teori motivasi yang paling popular dan berpengaruh besar dalam praktik pengembangan sumber daya manusia dalam suatu organisasi. Pertama, teori efek Hawthorn. Penelitian oleh Elton Mayo pada organisasi General Electric kawasan Hawthorn di Chicago, memiliki dampak pada motivasi kelompok kerja dan sikap individu dalam bekerja. Kontribusi hasil penelitian tersebut bagi perkembangan teori motivasi adalah: kebutuhan dihargai sebagai manusia ternyata lebih penting dalam meningkatkan motivasi dan produktivitas kerja individu dibandingkan dengan kondisi fiisik lingkungan kerja; sikap individu dipengaruhi oleh kondisi yang terjadi baik di dalam maupun di luar lingkungan tempat kerja; kelompok informal di lingkungan kerja berperan penting dalam membentuk kebiasaan dan sikap para individu; kerja sama kelompok tidak terjadi begitu saja namun harus direncanakan dan dikembangkan.

Kedua, teori kebutuhan. Menurut Maslow, pada dasarnya individu bekerja untuk memenuhi kebutuhan fisiologis, rasa aman, sosial, harga diri, dan aktualisasi diri. Kebutuhan-kebutuhan tersebut bersifat hierarkis, yaitu suatu kebutuhan akan timbul jika kebutuhan dasar sebelumnya telah dipenuhi. Setelah kebutuhan fisiologis seperti pakaian, makanan, dan perumahan terpenuhi, maka kebutuhan tersebut akan digantikan dengan kebutuhan rasa aman dan seterusnya. Sehingga tingkat kebutuhan seseorang akan berbeda-beda dalam bekerja. Seseorang yang kebutuhannya sekadar untuk makan, maka pekerjaan apa pun akan dilakukan untuk memenuhi kebutuhan tersebut.

Ketiga, teori X dan Y. McGregor mengemukakan dua model yang menjelaskan motivasi individu yang bekerja yaitu teori $\mathrm{X}$ dan teori $\mathrm{Y}$. Teori $\mathrm{X}$ menganggap bahwa individu tidak suka 
bekerja dan cenderung untuk menghindari kerja; individu harus diawasi dengan ketat dan diancam agar mau bekerja dengan baik; prosedur dan disiplin yang keras lebih diutamakan dalam bekerja; uang bukan satu-satunya faktor yang memotivasi kerja; dan individu tidak perlu diberikan kesempatan untuk mengembangkan diri. Sementara teori Y menganggap bahwa individu senang bekerja, sehingga pengawasan dan hukuman tidak diperlukan oleh individu; individu akan memiliki komitmen terhadap pekerjaan dan organisasi jika merasa memuaskan; manusia cenderung ingin belajar; dan kreativitas dan imajinasi digunakan untuk memecahkan masalah.

Keempat, teori hygine dan motivator. Menurut Herzberg, faktor yang menimbulkan kepuasan kerja individu berbeda dengan faktor yang menimbulkan ketidakpuasan kerja. Faktor-faktor tersebut adalah faktor hygine dan motivator. Faktor hygine meliputi kebijakan organisasi dan sistem administrasinya, sistem pengawasan, gaya kepemimpinan, kondisi lingkungan kerja, hubungan antarpribadi, gaji/upah, status, dan kesehatan dan keselamatan kerja. Sedangkan faktor motivator meliputi pengakuan, penghargaan terhadap prestasi, tanggung jawab yang lebih besar, pengembangan karier, pengembangan diri, minat terhadap pekerjaan.

Kelima, teori motivasi berprestasi. McClelland menjelaskan tentang keinginan seseorang untuk mencapai kinerja yang tinggi. Hasil penelitian tentang motivasi berprestasi menunjukkan pentingnya menetapkan target atau standar keberhasilan. Individu dengan ciri-ciri motivasi berprestasi yang tinggi akan memiliki keinginan bekerja yang tinggi. Individu lebih mementingkan kepuasan pada saat target telah tercapai dibandingkan imbalan atas kinerja tersebut. Hal ini bukan berarti mereka tidak mengharapkan imbalan, melainkan mereka menyukai tantangan.

Ada tiga macam kebutuhan yang dimiliki oleh setiap individu yaitu: kebutuhan berprestasi (achievement motivation) yang meliputi tanggung jawab pribadi, kebutuhan untuk mencapai prestasi, umpan balik dan mengambil risiko sedang; kebutuhan berkuasa (power motivation) yang meliputi persaingan dan memengaruhi orang lain; kebutuhan berafiliasi (affiliation motivation) yang meliputi persahabatan, kerja sama, dan perasaan diterima. Dalam lingkungan pekerjaan, ketiga macam kebutuhan tersebut saling berhubungan karena setiap individu memiliki semua kebutuhan tersebut dengan kadar yang berbeda. Seseorang dapat dilatih untuk meningkatkan salah satu dari tiga faktor kebutuhan. Misalnya untuk meningkatkan kebutuhan berprestasi kerja, individu dapat dipertajam tingkat kebutuhan berprestasi dengan menurunkan kebutuhan yang lain.

McClelland mengemukakan bahwa kinerja seseorang dapat dipengaruhi oleh virus mental yang ada pada dirinya. Virus tersebut merupakan kondisi jiwa yang mendorong seseorang untuk mencapai kinerja secara optimal. Ada tiga jenis virus sebagai pendorong kebutuhan, yaitu kebutuhan berprestasi, kebutuhan berafiliasi, dan kebutuhan berkuasa. Individu perlu mengembangkan virus tersebut melalui lingkungan kerja yang efektif untuk meningkatkan kinerja dan mencapai tujuan organisasi.

Motivasi berprestasi merupakan suatu dorongan dengan ciri-ciri seseorang melakukan pekerjaan dengan baik dan kinerja yang tinggi. Kebutuhan akan berprestasi tinggi merupakan suatu dorongan yang timbul pada diri seseorang untuk berupaya mencapai target yang telah ditetapkan, bekerja keras untuk mencapai keberhasilan, dan memiliki keinginan untuk mengerjakan sesuatu secara lebih lebih baik dari sebelumnya. Individu dengan motivasi berprestasi tinggi sangat menyukai tantangan, berani mengambil risiko, sanggup mengambil alih tanggung jawab, senang bekerja keras. Dorongan ini akan menimbulkan kebutuhan berprestasi individu yang membedakan dengan yang lain karena selalu ingin mengerjakan sesuatu dengan lebih baik. Berdasarkan pengalamam dan antisipasi dari hasil yang menyenangkan serta jika prestasi sebelumnya dinilai baik, individu lebih menyukai untuk terlibat dalam perilaku berprestasi. Sebaliknya, jika individu telah dihukum karena mengalami kegagalan, perasaan takut terhadap kegagalan akan berkembang dan menimbulkan dorongan untuk menghindarkan diri dari kegagalan. 
Ciri-ciri perilaku individu yang memiliki motivasi berprestasi yang tinggi menurut McClelland adalah menyukai tanggung jawab untuk memecahkan masalah; cenderung menetapkan target yang sulit dan berani mengambil risiko; memiliki tujuan yang jelas dan realistis; memiliki rencana kerja yang menyeluruh; lebih mementingkan umpan balik yang nyata tentang hasil prestasinya; dan senang dengan tugas yang dilakukan serta selalu ingin menyelesaikan dengan sempurna. Sebaliknya ciri-ciri individu yang memiliki motivasi berprestasi rendah adalah bersikap apatis dan tidak percaya diri; tidak memiliki tanggung jawab pribadi dalam bekerja; bekerja tanpa rencana dan tujuan yang jelas; ragu-ragu dalam mengambil keputusan; setiap tindakan tidak terahan dan menyimpang dari tujuan.

Laporan hasil penelitian tentang gaya manajerial dari 16.000 manajer di Amerika Serikat yang memiliki motivasi berprestasi yang tinggi, menengah, dan rendah menunjukkan sebagai berikut. Pertama, manajer dengan motivasi berprestasi yang rendah memiliki karakter pesimis dan tidak percaya dengan kemampuan bawahannya. Sedangkan manajer dengan motivasi berprestasi tinggi sangat optimis dan memandang bawahan baik dan menyenangkan. Kedua, motivasi manajer dapat diproyeksikan pada bawahannya. Bagi manajer yang bermotivasi prestasi tinggi selalu memerhatikan aspek-aspek pekerjaan yang harus diselesaikan dan mendiskusikan tugas pekerjaan yang harus dicapai bawahannya, sehingga mereka akan menerima. Ketiga, manajer yang bermotivasi berprestasi tinggi cenderung menggunakan metode partisipasi terhadap bawahannya, sedangkan manajer dengan motivasi berprestasi sedang dan rendah selalu menghindar dalam interaksi dan komunikasi terbuka. Keempat, manajer yang prestasinya tinggi lebih memerhatikan pada manusia dan tugas/produksi; manajer yang prestasinya sedang lebih memerhatikan tugas/produksi, sedangkan manajer yang prestasinya rendah hanya memerhatikan kepentingan pribadi dan tidak menghiraukan bawahannya.

Berdasarkan hasil penelitian tersebut dapat disimpulkan bahwa terdapat hubungan yang signifikan antara motivasi berprestasi dengan tingkat kinerja. Artinya, para individu yang memiliki motivasi berprestasi tinggi akan cenderung memiliki tingkat kinerja yang tinggi. Sebaliknya, mereka yang motivasi berprestasinya rendah kemungkinan akan memperoleh kinerja yang rendah.

\section{Metode Motivasi}

Beberapa teknik untuk memotivasi kerja adalah sebagai berikut. Pertama, teknik pemenuhan kebutuhan. Pemenuhan kebutuhan merupakan dasar bagi perilaku kerja. Motivasi kerja akan timbul jika kebutuhan dipenuhi seperti dikemukakan oleh Maslow tentang hierarki kebutuhan individu, yaitu: kebutuhan fisiologis (kebutuhan makan, minum, perumahan dan seksual). Kebutuhan ini paling mendasar bagi manusia sehingga dalam bekerja kebutuhan individu yang harus dipenuhi adalah gaji/upah yang layak. Lalu kebutuhan rasa aman, yaitu kebutuhan perlindungan dari ancaman bahaya dan lingkungan kerja. Dalam bekerja, individu memerlukan tunjangan kesehatan, asuransi dan dana pensiun. Kemudian, kebutuhan sosial, yaitu kebutuhan diterima dalam kelompok dan saling mencintai. Dalam hubungan ini, individu ingin diterima keberadaanya di tempat kerja, melakukan interaksi kerja yang baik dan harmonis. Setelah itu kebutuhan harga diri, yaitu kebutuhan untuk dihormati dan dihargai oleh orang lain. Dalam hubungan ini, individu butuh penghargaan dan pengakuan serta tidak diperlakukan sewenang-wenang. Terakhir, kebutuhan aktualisasi diri, yaitu kebutuhan untuk mengembangkan diri dan potensi. Dalam hubungan ini, individu perlu kesempatan untuk tumbuh dan berkembang secara pribadi.

Kedua, teknik komunikasi persuasif, adalah teknik memotivasi kerja yang dilakukan dengan cara memengaruhi dari luar diri. Rumus teknik komunikasi persuasif adalah ADIDAS, yang dijabarkan sebagai berikut. Attention, yaitu perhatian yang penuh; Desire, yaitu hasrat dan keinginan yang membara; Interest, yaitu minat dan kepentingan; Desicion, yaitu keputusan yang tepat; Action, yaitu tindakan nyata; Satisfaction, yaitu kepuasan atas hasil yang dicapai. 
Ketiga, teknik mengatasi masalah motivasi. Memotivasi merupakan salah satu faktor kunci untuk bekerja dan mencapai kinerja yang tinggi. Kegiatan memotivasi berkaitan dengan sejauh mana komitmen seseorang terhadap kinerjanya dalam rangka mencapai tujuan. Individu yang memiliki motivasi terhadap suatu kinerja rendah atau turun akan memiliki komitmen terhadap pelaksanaan penyelesaian kinerjanya. Individu tersebut termasuk orang yang kurang semangat atau bermotivasi rendah. Pada dasarnya, hal yang membuat individu kehilangan motivasi atau tidak semangat adalah situasi dan kondisi kinerja itu sendiri.

Untuk mengetahui apakah seorang individu memiliki motivasi yang tinggi dalam melakukan aktivitas dapat diketahui dengan mengamati individu dengan tanda-tanda: bersikap positif terhadap pekerjaannya, menunjukkan perhatian yang tulus terhadap pekerjaan orang lain dan membantu mereka bekerja lebih baik, selalu menjaga kesimbangan sikap dalam berbagai situasi, suka memberi motivasi kepada orang lain walaupun kadang tidak berhasil, dan selalu berpikir positif dari suatu kejadian. Sedangkan untuk mengetahui apakah seorang individu kehilangan motivasi tidak selalu mudah karena jarang diungkapkan. Namun hal ini dapat diketahui dari perubahan sikap yang terjadi pada dirinya yang dapat diamati. Tanda-tanda sikap individu yang tidak memiliki motivasi kerja adalah: tidak bersedia bekerja sama, tidak mau menjadi sukarelawan, selalu datang terlambat, pulang awal dan mangkir tanpa alasan, memperpanjang waktu istirahat dan bermain game dalam waktu kerja, tidak menepati tenggat waktu tugas, tidak mengikuti standar yang ditetapkan, selalu mengeluh tentang hal sepele, saling menyalahkan, dan tidak mematuhi peraturan.

Suatu hal yang perlu diperhatikan agar individu dan organisasi tidak mengalami kerugian akibat penurunan motivasi adalah dengan mengatasi masalah tersebut dan mencegah dengan berupaya mengantisipasi kondisi yang terjadi. Beberapa pendekatan untuk mengatasi atau mengurangi kekurangan semangat dan motivasi dalam melaksanakan pekerjaan adalah dengan pendekatan kuratif dan pendekatan preventif. Pendekatan kuratif atau mengatasi adalah melihat apakah masalah yang menimbulkan pengaruh pada motivasi penting atau tidak dalam pekerjaan. Jika masalahnya tidak terlalu penting, tidak perlu merasa putus asa. Namun jika ternyata masalah itu penting dalam pekerjaan, pembicaraan secara terbuka dan langsung dengan pihak yang berwenang -misalnya atasan atau konselor- untuk mendapatkan kesamaan persepsi sehingga jalan keluar dapat ditemukan. Jika pihak yang berwenang tidak dapat ditemui secara langsung, hubungi melalui surat atau telepon. Sementara pendekatan antisipatif, individu bekerja dengan sebaik-baiknya dan sesuai dengan ketentuan yang telah ditetapkan. Selanjutnya ia berusaha menenangkan hati sewaktu bekerja dan jangan terganggu dengan perasaan gelisah. Jika ia merasa gelisah karena hal-hal yang tidak berkaitan dengan pekerjaan, sebaiknya ia menenangkan diri di luar ruang kerja dengan cara yang diyakini berhasil, misalnya dengan berdoa atau yoga. Individu disarankan bersikap dan berpikir positif terhadap pekerjaan.

\section{SIMPULAN}

Pada umumnya banyak individu yang kurang termotivasi untuk berkinerja lebih tinggi lagi karena mereka melihat hubungan yang lemah antara upaya mereka dengan kinerja, antara kinerja dengan penghargaan, dan/atau antara penghargaan yang diterima dengan penghargaan yang diharapkan. Jika seorang menginginkan individu yang bermotivasi tinggi, ia harus melakukan hal yang diperlukan untuk memperkuat hubungan tersebut. Motivasi yang tinggi baik intrinsik maupun ekstrinsik terbukti memiliki dampak yang besar terhadap peningkatan kinerja individu dan pada gilirannya mendorong pertumbuhan kinerja organisasi. Artinya bahwa, makin besar motivasi individu maka akan makin positif kinerja individu dan organisasi. 
Upaya untuk meningkatkan kinerja individu dalam organisasi memerlukan strategi motivasi dengan menggunakan metode motivasi. Metode yang efektif untuk meningkatkan motivasi adalah teknik pemehuan kebutuhan dan teknik komunikasi persuasif. Sedangkan teknik motivasi untuk mengatasi penurunan motivasi adalah pendekatan kuratif dan pendekatan preventif. Selain itu, teknik penilaian kinerja dan manajemen kinerja yang objektif, transparan, dan adil sangat penting dalam memotivasi individu.

\section{DAFTAR PUSTAKA}

Cameron, J., Pierce,W. D. (1994). Reinforcement, reward, and intrinsic motivation: a meta-analysis. Review of Educational Research.

Ismail, R. W. (2012, 7 April). 2 Faktor Motivasi. Diakses dari http://tipsmotivasi.com/2012/04/07/2faktor-motivasi/

Locke, E. A.(1968). Toward a Theory of Task Motivation and Incentive, Organizational Behavior and Human Performance.

Maslow, A. (1954). Motivation and Personality. New York: Harper \& Row.

McClelland, D.C. (1961). The Achieving Society. New York: Van Nostrand Reinhold.

Robbins, S. P., Judge, T. A. (2008). Perilaku Organisasi. Jakarta: Salemba Empat.

Wikipedia. (n.d.). Kinerja. Diakses dari http://id.wikipedia.org/wiki/Kinerja. 